\title{
IMPLEMENTASI METODE JOB ORDER COSTING PADA HARGA JUAL DI BATIK CELAKET MALANG
}

\author{
Aan Invado \\ Jurusan Akuntansi Fakultas Ekonomi \\ Universitas Islam Negeri Maulana Malik Ibrahim Malang \\ Jl. Gajayana 50 Malang Telp. 0341-551354
}

\begin{abstract}
Batik Celaket is a unit business engaged in the field of the craft in the manufacture of batik. Business unit batik celaket has not done calculation basic price production with right as the basis the selling price. This is because the batik celaket did not do in any transaction could not collect data so that financing is. This less effective and efficient because the selling price products can be determined with calculating the cost of production first. The purpose of this research is the implementation of a method of job order costing on the selling price in Batik Celaket Malang.This research uses descriptive quantitative approach is done in Batik Celaket business units. The research is a kind of descriptive, namely to draw the sample and showed a picture of the reality us empirically occur in the field. Because the data obtained from the observation directly in the business unit of Batik Celaket and then implemented by calculation the cost of goods sold production uses the method job order costing jualnya to determine prices. The results showed that Celaket Batik business units have yet to calculate the cost of goods production in determining the selling price. Once identified and grouped, calculation of cost of goods production is done using the method of job order costing batik shirts on order in June for a total of Rp 9,095,234 with a price of staple production each Rp 90,952. With mark-up 12\% from the results of the method of job order costing Rp 102,000 then found the company set the price too low causing haven't gotten profits as expected.
\end{abstract}

Keywords :The cost of production, job order costing, the selling price.

\begin{abstract}
Abstrak
Batik Celaket Malang merupakan unit usaha yang bergerak di bidang kerajinan dalam pembuatan batik. Unit usaha Batik Celaket belum melakukan perhitungan harga pokok produksi dengan tepat sebagai dasar penentuan harga jual. Hal tersebut terjadi karena Batik Celaket sendiri belum melakukan pencatatan di setiap transaksi yang ada sehingga tidak dapat mendata pembiayaan yang ada. Hal tersebut kurang efektif dan efisien karena harga jual produk dapat ditentukan dengan menghitung harga pokok produksinya terlebih dahulu. Tujuan dari penelitian adalah implementasi metode job order costingpada harga jual di Batik Celaket Malang.Penelitian ini menggunakan pendekatan deskriptif kuantitatif yang dilakukan di unit usaha Batik Celaket. Penelitian yang merupakan jenis deskriptif yaitu untuk menarik sampel dan menunjukkan gambaran kenyataan secara empiris sesuai yang terjadi di lapangan. Data diperoleh dari hasil observasi langsung di unit usaha Batik Celaket dan kemudian diimplementasikan dengan perhitungan harga pokok produksi menggunakan metode job order costinguntuk menentukan harga jualnya.Hasil penelitian menunjukkan bahwa unit usaha Batik Celaket belum menghitung harga pokok produksi dengan tepat dalam menentukan harga jualnya. Setelah diidentifikasi dan dikelompokkan, perhitungan harga
\end{abstract}


pokok produksi dilakukan dengan menggunakan metode job order costing pada pesanan kemeja batik di bulan Juni dengan total Rp 9.095.234 dengan harga pokok produksi tiap unit Rp 90.952. Keuntungan yang diinginkan sebesar $12 \%$. Dengan mark-up $12 \%$ dari hasil metode job order costing diperoleh Rp 102.000.

Kata Kunci : Harga Pokok Produksi, Job order costing, Harga Jual 


\section{PENDAHULUAN}

Perusahaan pada dasarnya bertujuan untuk mendapatkan laba yang optimal. Pihak manajemen diharuskan mampu dalam mengelola perusahaan secara baik agar dapat mencapai laba yang optimal. Dalam mencapai laba yang optimal dapat dilakukan dengan menetapkan harga jual sedemikian rupa sesuai dengan laba yang diinginkan. Hal tersebut dengan memperhitungkan harga produksinya terlebih dahulu.

Harga pokok produksi merupakan cara untuk memperhitungkan unsur-unsur biaya dalam suatu produksi. Penentuan harga pokok produksi merupakan hal yang sangat penting bagi perusahaan industri, karena selama proses masukan (bahan mentah) menjadi keluaran (bahan jadi) begitu banyak biaya-biaya yang terjadi dalam perusahaan, misalnya: biaya bahan baku, biaya tenaga kerja langsung, dan biaya pabrik tidak langsung. Biaya-biaya tersebut harus diperhitungkan untuk menentukan besarnya biaya produksi untuk memproduksi suatu jenis produk pada unit tertentu, atau dapat dikatakan untuk penentuan harga pokok produksi pada suatu produk yang diproduksi (Cristian, 2016).

Harga pokok produksi dapat dihitung dengan berbagai metode. Akuntan manajemen harus membuat tiga pilihan untuk menentukan metode penghitungan harga pokok produksi yang tepat. Pilihan sistem tertentu bergantung pada sifat industri dan produk atau jasa, strategi perusahaan, dan kebutuhan informasi bagi pihak manajemen, serta biaya dan manfaat dari perolehan, perencanaan, perubahan, dan pelaksanaan sistem tertentu (Blocher, Stout, dan Cokins, 2011:14)

Menurut menurut Mulyadi (2009:42) cara memproduksi produk dibagi menjadi dua macam, yaitu produksi atas dasar pesanan dan produksi masa. Produksi atas masa menggunakan metode harga pokok proses, yaitu suatu metode untuk membebankan biaya produk sejenis yang diproduksi secara masal, berkesinambungan lewat serangkaian langkah produksi. Metode harga pokok proses merupakan metode pengumpulan harga pokok produk dimana biaya dikumpulkan untuk setiap satuan waktu tertentu, misalnya : bulan, triwulan, semester, tahun. Pada metode harga pokok proses perusahaan menghasilkan produk yang homogen, bentuk bersifat standar, dan tidak tergantung spesifikasi yang diminta oleh pembeli (Supriyono, 2010:36).

Sedangkan sistem perhitungan biaya berdasarkan pesanan digunakan untuk perusahaan yang memproduksi berbagai produk selama periode tertentu (Garrison, 2006:123).Pada era ini banyak perusahaan yang berbentuk UMKM. Berkembang dan banyak 
bermunculan pelaku usaha UMKM, maka era ekonomi ini menyebabkan tingkat persaingan yang tinggi. Timbulnya angka usaha yang melonjak, menyebabkan persaingan dari para pelaku usaha untuk mempertahankan usahanya. Potensi dari UMKM harus dikembangkan secara menyeluruh agar dapat bersaing. Strategi dalam hal bisnis juga perlu ditingkatkan, khusunya pada aspek penetapan biaya produksi. Berbagai peran strategis dimiliki sektor UMKM, namun sektor ini juga dihadapkan pada berbagai permasalahan, antara lain masalah pada aspek permodalan, kemampuan manajemen usaha, dan kualitas sumber daya manusia pengelolanya (Supriyanto, 2006:2).

Sebagai sebuah bisnis, alangkah baiknya bagi UMKM untuk melakukan pengambilan keputusan berdasarkan dengan keuangan yang terjadi di lingkup usahanya. Langkah tersebut yaitu dengan menentukan harga jual produknya. Hal ini dilakukan agar UMKM dapat mendapatkan keuntungan yang maksimal. Dengan memaksimalkan keuntungan yang ada, maka laba yang didapatakan sesuai.Namun hal itu belum dapat terwujud secara maksimal. Dikarenakan umumnya UMKM masih berwujud usaha milik keluarga, menggunakan teknologi yang masih relatif sederhana, kurang memiliki akses permodalan, dan tidak ada pemisahan modal usaha dengan kebutuhan pribadi.

Keterbatasan inilah yang kemudian memunculkan permasalahan pada UMKM. Permasalahan tersebut adalah keputusan penentuan harga jual. Penentuan harga jual sangat penting dan dapat menjadi suatu keunggulan kompetitif bagi UMKM karena penentuan harga jual yang terlalu tinggi akan mempengaruhi daya saing di pasaran dan apabila penentuan harga jual terlalu rendah akan memberikan dampak jangka panjang yang mempengaruhi penerimaan laba yang tidak sesuai target atau bahkan mengalami kerugian.

Agar dapat menentukan harga jual yang tepat UMKM harus dapat menghitung harga pokok produksi secara akurat. Harga pokok produksi adalah cerminan total biaya barang yang diselesaikan selama periode berjalan. Harga pokok produksi merupakan suatu biaya yang digunakan untuk memproduksi suatu barang dalam suatu periode waktu tertentu yang terdiri dari biaya bahan baku, biaya tenga kerja, dan biaya overhead pabrik.

Usaha mikro, kecil dan menengah atau biasa di singkat UMKM merupakan unit usaha yang bergerak di berbagai bidang industri merupakan kegiatan ekonomi rakyat yang produktif dan dapat menyediakan banyak peluang kerja, mengurangi kemiskinan, pengangguran, juga sebagai sarana perputaran keuangan. Dalam surat Al-Hasyr ayat 7, yaitu: 


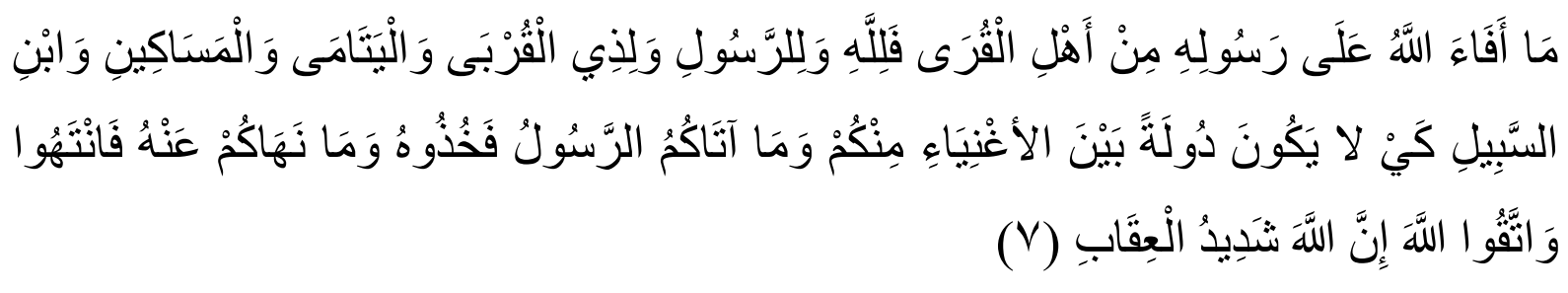

"Harta rampasan fai'i yang diberikan Allah kepada Rasul-Nya (yang berasal) dari penduduk beberapa negeri, adalah untuk Allah, rasul, kerabat (rasul), anak-anak yatim, orang-orang miskin dan untuk orang-orang yang dalam perjalanan, agar harta itu jangan hanya beredar di antara orang-orang kaya saja di antara kamu. Apa yang diberikan Rasul kepadamu, maka terimalah. Dan apa yang dilarangnya bagimu, maka tinggalkanlah. Dan bertakwalah kepada Allah. Sungguh, Allah sangat keras hukumannya.”. (Q.S. Al-Hasyr [59]: 7)

Menurut ayat tersebut bahwa Allah SWT melarang berputarnya harta yang hanya di kalangan orang-orang kaya saja. Dari ayat tersebut dimaksudkan agar aktivitas perekonomian hendaknya melibatkan partisipasi aktif dari kelompok masyarakat menengah - bawah, yang notabenenya mayoritas penduduk di suatu negara. Menolong kaum lemah di negeri ini dengan mengembangkan UMKM secara bersama-sama.

Pada penelitian ini akan mengambil objek salah satu UMKM di Kota Malang. Dikarenakan banyaknya UMKM di Kota Malang yang berkualitas dan siap bersaing, juga sudah menyebar keberbagai sector usaha. Pelaku Usaha Mikro, Kecil dan Menengah (UMKM) dan Koperasi di Kota Malang memberikan dampak cukup signifikan bagi pertumbuhan ekonomi di Kota Malang yang mencapai 5,61 persen. Angka tersebut melebihi nilai rata-rata Provinsi Jawa Timur yang hanya 5,5 persen (Ara, 2017).

Dengan kehadiran UMKM tersebut dapat memangkas angka pengguran di Kota Malang. Hal ini dibuktikan dengan penerimaan penghargaan Natamukti Pranata pada tahun 2016 oleh Kota Malang, karena Kota Malang dianggap berhasil mendorong kemajuan Usaha Mikro, Kecil dan Menengah. Salah satunya di bidangkerajinan, Kota Malang sudahmemilikisentral batik tersendiri. Perkembangankerajinan batik di Kota Malang sangatpesat. Pemasarandanpenjualannyasudahmenembus level nasionaldaninternasional. (Achmad, 2013).

Batik Celaket Malang merupakan salah satu unit usaha bergerak di bidang kerajinan batik tulis. Usahanya yaitu membuat atau memproduksi sendirikain batik tulis khas malang.Sebagai unit usaha yang lebih menjalankan produksi atas dasar pesanan, maka salah satu metode yang dapat digunakan dalam menentukan harga pokok produksinya yaitu job order costing. Sistem perhitungan biaya berdasarkan pesanan (job order costing) digunakan 
untuk perusahaan yang memproduksi berbagai produk selama periode tertentu (Blocher, Stout, danCokins, 2011:123). Metode ini digunakan dalam pekerjaan produksi yang berdasarkan pesanan dan hal itu sesuai dengan Batik Celaket yang produksinya menerima pesanan dari pelanggan.

Akan tetapi pada Batik Celaket sendiri juga belum paham akan hal ini dan tidak melakukan pencatatan keuangan dengan semestinya. Batik Celaket tidak melakukan pengelolaan keuangan yang sesuai dengan akuntansi. Sedangkan sebagian besar produksi usahanya masih berdasarkan pesanan. Dilihat dari penjelasan tersebut, maka diperlukan evaluasi mengenai perhitungan Batik Celaket Malang berdasarkan metode job order costing.

Menurut Mulyadi (2009:42) cara memproduksi produk dibagi menjadi dua macam, yaitu produksi atas dasar pesanan dan produksi masa. Perusahaan yang berproduksi berdasarkankan pesanan melaksanakan pengolahan produknya atas pesanan yang diterima dari pihak luar, contohnya perusahaan percetakan, perusahaan mebel dan sebagainya. Perusahaan yang memproduksi berdasarkan produksi masa melaksanakan produksinya untuk memenuhi persediaan gudang. Umumnya produknya berupa produk standar, contohnya perusahaan semen, perusahaan pupuk, bumbu masak, tekstil dan lain sebagainya. Perusahaan yang berproduksi berdasarkan pesanan mengumpulkan harga pokok produksinya dengan menggunakan metoode harga pokok pesanan (job order cost method). Sedangkan perusahaan yang berproduksi masa, mengumpulkan harga pokok produksinya dengan menggunakan metode harga pokok proses (process cost method).

Sistem perhitungan biaya berdasarkan pesanan digunakan untuk perusahaan yang memproduksi berbagai produk selama periode tertentu (Garrison, 2006:123). Sistem ini digunakan pada perusahaan yang mengolah produksinya berdasarkan pesanan dari pelangggan. Bastian dan Nurlela (2013:61) dalam bukunya menyatakan bahwa perhitungan biaya merupakan salah satu metode atau cara mengakumulasi biaya, yang dapat diterapkan pada perusahaan yang menggunakan produksi terputus-putus. Dimana dalam metode ini, biaya dikumpulkan untuk setiap pesanan secara terpisah sesuai dengan identitas masingmasing pesanan atau kontrak. Kontrak sendiri harus didasari dengan persetujuan diantara kedua belah pihak. Sesuai dengan surat An-Nisa' ayat 29

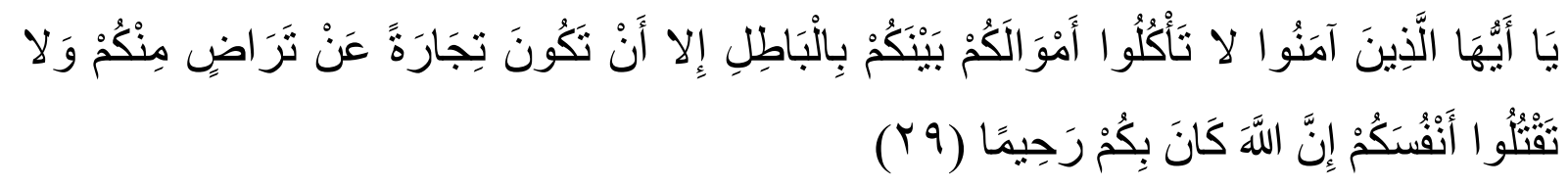


"Hai orang-orang yang beriman, janganlah kamu saling memakan harta sesamamu dengan jalan yang batil, kecuali dengan jalan perniagaan yang berlaku dengan suka sama-suka di antara kamu." (Q.S. An-Nisa' [4]: 29)

Maksud dari ayat tersebut agar perdagangan terjadi atas dasar kesepakatan dari kedua belah pihak yang nantinya diharapkan akad perdagangan tersebut bukan akad riba, karena riba bukan termasuk perdagangan, bahkan menyelisihi maksudnya, dan bahwa kedua belah pihak harus suka sama suka dan melakukannya atas dasar pilihan bukan paksaan. Untuk menentukan biaya berdasarkan pesanan secara teliti dan akurat, setiap pesanan harus dapat diidentifikasi secara terpisah dan terlihat secara terperinci dalam kartu biaya pesanan untuk masing-masing pesanan. Dan perhitungan biaya berdasarkan pesanan dapat diterapkan untuk pekerjaan pada perusahaan manufaktur, pekerjaan kontruksi, industri percetakan, jasa pelayanan hukum, jasa arsitek, jasa akuntansi serta jasa konsultasi lainnya.

Manfaat yang diperoleh perusahaan yang menghitung harga pokok produksinya dengan menggunakan job order costing menurut Mulyadi (2015:41) adalah sebagai berikut :

1. Perusahaan dapat menentu kan harga jual yang dibebankan kepada pesanan

2. Perusahaan dapat mempertimbangkan untuk menerima atau menolak pesanan

3. Perusahaan dapat memantau biaya produksi, perusahaan dapat menghitung laba atau rugi setiap pesanan

4. Perusahaan dapat menentukan harga pokok persediaan produk jadi dan produk dalam proses yang disajikan dalam neraca

Perhitungan biaya berdasarkan pesanan merupakan sistem perhitungan biaya yang mengakumulasikan biaya dan membebankannya pada pesanan pelanggan, proyek, atau kontrak tertentu (Blocher dkk., 2011:152). Dokumen pendukung dasar dalam sistem perhitungan biaya berdasarkan pesanan adalah kartu biaya pesanan, kartu ini mencatat dan meringkas biaya bahan baku langsung, tenaga kerja langsung, dan overhead pabrik untuk pekerjaan tertentu.

i. Biaya bahan baku langsung

Formulir permintaan bahan baku (material requisition) adalah dokumen sumber atau pencatatan data secara online yang digunakan departemen produksi untuk meminta bahan baku produksi. Formulir permintaan bahan mengindikasikan pesanan khusus yang dibebankan berdasarkan bahan baku yang digunakan. Bahan baku tidak langsung di perlakukansebagaibagiandari total biaya overhead pabrik. Bahan baku tidak langsung yang biasanya digunakan dalah lem, paku, dan peralatan pabrik.

ii. Biaya tenaga kerja langsung dan tidak langsung 
Biaya tenaga kerja langsung dicatat dalam kartu biaya pesanan berdasarkan kartu jam kerja yang disiapkan setiap hari untuk setiap karyawan. Kartu jam kerja merupakan bagian dari sistem peranti lunak perhitungan biaya yang menunjukkan lama pekerjaan yang dilakukan oleh seorang karyawan pada setiap pesanan, tarif gaji, dan biaya total yang dibebankan pada setiap pesanan. Analisis kartu jam kerja akan menyediakan informasi mengenai biaya tenaga kerja langsung yang dapat dibebanklan kedalam pesanan. Biaya tenaga kerja tidaklangsungdiperlukansebagai total biayaoverheadpabrik. Biaya tenaga kerja tidak langsung meliputi gaji bagi penyelia, pemeriksa dan petugas gudang.

iii. BiayaOverheadPabrik

Menurut Blocher metodepengukuran biaya dalam sistem perhitungan biaya berdasarkan pesanan maupun perhitungan biaya berdasarkan proses dapat diukur sebesar jumlah biaya sesungguhnya, normal ataustandar. Pembebanan biaya overhead (overheadapplication) merupakan proses pengalokasian biaya overhead pada pesanan. Biaya overhead ini dialokasikan karena biaya overhead tidak dapat ditelusuri ke tiap tiap pesanan. Menurut Blocher metode pembebanan biaya overhead terdiri dari:

a) Sistem Tradisional (traditional costing)

Sistem penentuan biaya produk tradisional sering mengalokasikan biayaoverhead keproduk atau pesanan berdasarkan cost driver volume, seperti unit yang diproduksi, biaya tenaga kerja langsung atau jam kerja langsung. Dalam system ini pembebanan biaya overhead dibebankan dalam jumlah yang sama pada setiap produk atau yang biasa disebut sebagai volume based system. Metode ini menganggap biaya overhead pabrik proporsional dengan jumlah unit yang diproduksi. Mulyadi menyatakan system tradisional konvensional membebankan biaya overhead pabrik kepada produk melalui dua tahap, yaitu:

I. Tahap pertama, biaya overhead pabrik dikumpulkan dalam pusat biaya, baik departemen pembantu maupun departemen produksi dengan menggunakan alokasi tertentu.

II. Tahap kedua, biaya overhead pabrik yang telah melalui agregasi tahap pertama dibebankan kepada produk atas dasar jam tenaga kerja langsung, jam mesin, atau biaya tenaga kerja langsung. Sistem pembebanan biaya overhead tradisional mudah di terapkan dikarenakan system pembebanan biaya overhead tradisional tidak memakai banyak pemicu biaya (cost driver) dalam mengalokasikan biaya overhead sehingga 
memudahkan bagi manajer untuk melakukan perhitungan Harga Pokok Produksi sehingga system pembebanan biaya overhead ini cocok dilakukan oleh UMKM.

1. Sistem Berdasarkan Aktivitas (activity based costing)

Menurut Raiborn dan Kinney (2014:150) Activity Based Costing adalah sistem akuntansi biaya yang berfokus kepada aktivitas organisasi dan pengumpulan biaya-biaya berdasarkan sifat pokok yang masihmendasaritingkatbeberapaoverhead yang telahditetapkandankemudian dihitung menggunakan berbagai macam pemicu biaya dalam aktivitas suatu organisasi. Menurut Garrison (2006:312) Activity Based Costing adalah metode perhitungan biaya yang dirancang untuk menyediakan informasibiayabagimanajeruntukkeputusanstrategisdankeputusanlainnya.

Tarif alokasi overhead yang ditentukan terlebih dahulu digunakan membebankan biaya overhead pabrik ke dalam pesanan tertentu. Agar dapat menghitung tarif overhead pabrik yang ditentukan dimuka dapat dilakukan melalui empat langkah (Blocher dkk., 2011:159):

a) Mengestimasi total biaya overhead pabrik untuk periode operasi yang sesuai, biasanya satu tahun

b) Memilih penggerak biaya (cost driver) yang paling tepat untuk membebankan biaya overhead pabrik

c) Mengestimasi total jumlahpenggerak biaya terpilih untuk periode operasi

d) Mengestimasi total jumlahpenggerak biaya terpilih untuk periode operasi

Berdasarkan pengertian diatas dapat diambil kesimpulan bahwa sistem biaya berdasarkan aktivitas mengalokasikan biaya overhead ke produk dengan menggunakan kriteria sebab akibat dengan banyak cost driver. Sistem ini menggunakan cost driver berbasis volume dan cost driver yang tidak berbasis volume supaya dapat mengalokasikan biaya overhead pabrik secara lebih akurat ke produk yang mendasarkan konsumsi sumber daya pada berbagai aktivitas.

Pembebanan biaya overhead berdasarkan aktivitas akan memerlukan usaha yang ekstra bagi manajemen untuk mengumpulkan data data yang dibutuhkan untuk melakukan perhitungan biaya hal ini menyebabkan pembebanan biaya overhead berdasarkan aktivitas kurang cocok apabila diterapkan dalam UMKM dikarenakan data yang berhubungan dengan biaya yang dimiliki oleh UMKM masih sangat sederhana sehingga manajemen akan kesulitan dalam menentukan cost driver - cost driver yang di perlukan untuk pembebanan biaya overhead berdasarkan aktivitas. 
Setiap kegiatan memiliki masukan dan keluaran. Masukan sendiri dalam proses produksi merupakan hal yang digunakan dalam pencapaian suatu hasil yang kemuadian menjadi carang jadi. Hal seperti ini bisa juga disebut perilaku biaya. Perilaku biaya menjelaskan bagaimana biaya masukan kegiatan berubah dalam kaitannya dengan perubahan pada kegiatan. Oleh karena itu, untuk menilai perilaku biaya kegitan tersebut harus ditentukan., keluaran dan masukannya harus ditentukan, diuku serta berpengaruh pada biaya masukan seperti halnya perubahan keluran kegiatan harus dihitung. Mungkin tugas yang paling sukar dalam menilai perilaku biaya adalah dengan mengidentifiasi ukuran keluatan kegiatan yang baik (Hansen dan Mowen, 2000:38).

Pemilahan yang akurat dan sesuai akan mempermudah perhitungan secara sistematis untuk menemukan hasil yang diinginkan. Oleh karena itu penerapan job order costing dapat digunakan dalam perhitungan harga pokok produksi. Manajemen perusahaan dapat mengetahui kecenderungan-kecenderungan (tren) dan problem-problem pada kegiatan perusahaan serta dapat mengembangkan strategi yang tepat untuk memperbaiki kinerja perusahaan.

Salah satu keputusan penting yang dapat mempengaruhi daya saing perusahaan adalah pengambilan keputusan mengenai harga jual produk. karena penentuan harga jual yang terlalu tinggi akan mempengaruhi daya saing perusahaan di pasaran dan apabila penentuan harga jual terlalu rendah maka akan memberikan dampak jangka panjang yang mempengaruhi penerimaan laba yang tidak sesuai target atau bahkan mengalami kerugian.

Harga jual juga harus diperhitungkan dengan kesesuaiannya. Seperti yang disebutkan pada Al-Qur'an surat Al-Isra' ayat 35 berikut ini:

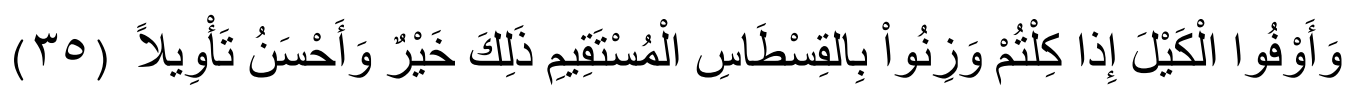

"Dan sempurnakanlah takaran apabila kamu menakar, dan timbanglah dengan neraca yang benar. Itulah yang lebih utama (bagimu) dan lebih baik akibatnya”. (QS. Al-Isra' [17]: 35)

Dari ayat di atas dapat dimaknai bahwa dalam menentukan harga jual haruslah dengan kesesuaian yang wajar. Ayat ini mengingatkan untuk selalu memperhatikan dengan jujur dan tepat takaran dan timbangan apa yang kita perdagangkan dan jangan sampai melakukan kecurangan. Dikarenakan hal tersebut akan berpengaruh dengan hasil dagang kita yang baik. Maksud dari baik, yaitu dengan harga yang wajar, barang dagang kita akan laku untuk terjual. 
Hansen dan Mowen (2001:633) dalam bukunya menjelaskan bahwa harga jual adalah jumlah moneter yang dibebankan oleh suatu unit usaha kepada pembeli atau pelanggan atas barang atau jasa yang dijual atau diserahkan.

Menurut Garisson (2006:531) pendekatan yang umum dalam penentuan harga adalah Markup biaya. Markup produk adalah perbedaan antara harga jual dengan biayanya yang biasa dinyatakan sebagai persentase dari biaya.

Harga jual $=$ biaya $+($ persentase markup $\mathrm{x}$ biaya $)$

Pendekatan ini disebut perhitungan biaya-plus (cost-plus pricing) karena persentase markup yang ditentukan sebelumnya diterapkan pada dasar biaya untuk menentukan harga jual. Berdasarkan penelitian terdahulu dan kondisi yang ada pada Batik Celaket, maka peneliti termotivasi untuk melakukan penelitian mengenai pengimplementasian metode job order costing di Batik Celaket dengan judul penelitian "Implementasi Metode Job order costing pada Harga Jual di Batik Celaket Kota Malang”.

\section{PEMBAHASAN}

Pengolahan pembiayaan pada Batik Celaket masih berupa data kasar, dalam artian belum mengalami pencatatan dan juga pengelompokan biaya secara terperinci. Unit usaha belum pernah membuat laporan keuangan secara terperinci selama 10 tahun masa kerjanya. Oleh karena itu data peneliti dapatkan dari hasil wawancara langsung dengan ibu Ira selaku pemilik usaha. Hasil dari wawancara dapat dilihat pada lampiran satu. Penghitungan masih dilakukan secara sederhana tanpa ada laporan keuangan tertulis.

Untuk memenuhi kebutuhan penelitian atas periode waktu yang dibutuhkan, maka pada penelitian ini menetapkan penelitian untuk data produksi pesanan kemeja oleh SD Rampal Celaket dengan jumlah 100 potong yang dikerjakan mulai bulan Juni sampai Agustus 2017. Proses pengerjaannya sendiri hanya dua minggu di Batik Celaket, sedangkan satu bulan pada peroses penjahitan. Berkenaan dengan produksi berupa pesanan, maka digunakan perhitungan harga pokok produksi menggunakan metode job order costing. Sebelum melakukan penghitungan harga pokok produksi, maka akan dilakukan pengidentifikasian biaya produksi dan pengelompokkan biaya produksi.

Sebelum dilakukan perhitungan harga pokok produksi menggunakan metode job order costing maka diperlukan pengidentifikasian biaya produksi dan pengelompokan biaya. Pengidentifikasian biaya tersebut ditujukan untuk menentukan biaya apa saja yang dikeluarkan guna memenuhi produksi pesanan. Biaya tersebut antara lain: Kain Katun Primisima, lilin (malam), pewarna, biaya tenaga kerja pembatikan, biaya penjahitan, biaya 
air, biaya bahan bakar, biaya bahan kimia, biaya konsumsi karyawan, biaya sewa gedung, biaya penyusutan peralatan, biaya gaji mandor.

Setelah melakukan pengidentifikasian biaya produksi maka selanjutnya adalah melakukan pengelompokkann biaya produksi. Biaya produksi adalah biaya yang digunakan dalam proses produksi yang terdiri bahan baku langsung, tenaga kerja langsung, dan biaya overhead pabrik. Berikut yang termasuk kelompok biaya produksi:

1. BiayaBahan Baku

Bagian yang termasukdalambiayabahanbakuadalahkainkatunprimisima.

2. Biaya Tenaga Kerja

Bagian yang termasuktenaga kerja adalah pembatik dan penjahit.

\section{BiayaOverheadPabrik}

Padabiayaoverheadtedapatbiayabahanbakupenolong, yaitu pewarna, lilin dan biaya bahan kimia yang digunakan untuk penguat warna bagi kain batik. Lalu biaya operasional produksi berupa biaya air, biaya bahan bakar berupa elpiji, biaya konsumsi karyawan, biayasewagedung, biayapenyusutanperalatan, biayagajimandor.

Berdasarkan biaya produksi yang telah dikelompokkan maka langkah selanjutnya adalah melakukan penghitungan agar dapat diketahui mengenai harga pokok produksi. Berikut merupakan perhitungan biaya untuk harga pokok produksi pada Batik Celaket, yaitu:

1. BiayaBahan Baku

Penghitunganbiayabahanbaku dihitung dengan cara mengalikan jumlah kuantitas bahan baku yang digunakan dengan harga bahan baku tersebut. Berikut bahan baku yang dibutuhkan dalam proses pembuatan kemeja batik sebanyak 100 unit pada bulan Juni 2017 untuk memenuhi pesanan SD Rampal Celaket adalah kain katun primisima. Bahan baku dasar dari pembuatan batik yaitu kain katun primisima yang dijual tiap meternya Rp 25.000. Untuk membuat satu unit baju membutuhkan setengah helai batik. Jadi satu helai batik dapat digunakan menjadi dua unit kemeja. Ukuran dari satu helai batik adalah 2,3 m dengan lebar $115 \mathrm{~cm}$. Sedangkan panjang baju adalah $55 \mathrm{~cm}$ dengan lingkar badan $80 \mathrm{~cm}$. Penggunaan bahan satu helai kain cukup untuk menjadikan dua kemeja batik. Sehingga untuk pesanan100 unitkemejamembutuhkan 50 helaikain batik.

2. Biaya Tenaga Kerja

Tenaga kerjaadalahtenagamanusia yang bekerja langsung mengolah produk. Penghitungan biaya tenaga kerja dihitung dengan mengalikan jumlah karyawan dengan upah per hari kerja serta jumlah hari kerja dalam melakukan aktivitas produksi. Juga pada produksi penjahitan dengan mengalikan jumlah unit dengan upah produksi. Berikut 
tenaga kerja yang dibutuhkan dalam membuat kemeja batik sebanyak 100 unit selama bulan Juni 2017 untuk memenuhi pesanan SD Rampal Celaket adalah:Tenaga kerja PembatikanProses produksi pada pesanan kemeja melibatkan 7 orang pegawai yang semua turut langsung pada proses produksi. Pembiayaan karyawan tidak dilihat dari berapa jumlah produksinya, namun karyawan digaji untuk tiap harinya Rp 20.000. Pengerjaan 50 helai batik menghabiskan waktu 12 hari dan dilakukan oleh Batik Celaket. Jadi setiap karwayan mendapat pembayaran Rp 240.000 untuk penyelesaian pesanan.Tenaga kerja PenjahitanSedangkan penjahitan diberikan kepada penjahit diluar usaha Batik Celaket. Proses penjahitan menghabiskan waktu satu setengah bulan sampai selesai 100 unit baju. Untuk penjahitan yang menggunakan jasa luar, penjahit mematok harga Rp 12.000 per unit kemeja yang sudah jadi.

3. Biaya Overhead Pabrik

Berdasarkan penelitian yang dilakukan terdapat beberapa komponen biaya overhead yang belum dimasukan atau dibebankan ke dalam harga pokok produksi. Berikut adalah informasi mengenai biaya overhead aktual yang dikeluarkan unit usaha berdasarkan hasil penelitian:

a. Biaya penolong

Terdapat 3 unit bahan baku penolong pada produksi pesanan, antara lain:

\section{Lilin (Malam)}

Lilin atau malam merupakan salah satu bahan baku untuk pembuatan batik. Fungsi dari bahan baku ini adalah untuk menutupi bagian tertentu agar tidak terkena pewarna. Lilin yang digunakan sejumlah 5 kg dengan harga per kilonya Rp 80.000.

\section{Pewarna}

Pewarna adalah salah satu unsur pesona batik. Pewarna yang digunakan total seluruhnya $1 \mathrm{~kg}$ dengan harga per kilonya 100.000 .

\section{Bahan kimia}

Merupakan bahan yang digunakan sebagai penguat batik agar warna batik tidak mudah luntur, harga bahan kimia tersebut yang digunakan pada pesanan Rp 7.000.

b. Biaya bahan bakar

Bahan bakar yang digunakan oleh Batik Celaket berupa gas tabung elpiji yang setiap unitnya Rp 17.000. Untuk menyelesaikan pesanan dibutuhkan 10 unit elpiji yang akhir dapat diketahui biaya untuk bahan bakar sebesar Rp 100.000. 
c. Biaya penyusutan

Penyusutan yang terjadi pada proses pembuatan kemeja ini berada pada pembuatan batiknya, yaitu penyusutan pada peralatan yang digunakan untuk membatik. Antara lain alat cap, meja, kursi, loyang dan kompor. Untuk perhitungan biaya penyusutan peralatan disajikan dalam lampiran 2. Total biaya penyusutan per bulan Rp 63.133, dengan pengerjaan yang menghabiskan waktu dua minggu maka penyusutan peralatan untuk pesanan tersebut Rp 31.567.

d. Biayasewa

Gedung yang digunakan merupakan tempat produksi yang menyewa dengan harga sewanya Rp 25.000.000 per tahun. Dengan waktu produksi di gedung yang hanya 12 hari atau 2 minggu, biaya sewa gedung dihitung dengan membagi Rp 25.000.000 dengan 12 bulan, kemudian dibagi 2, jadi biaya sewa gedung Rp 1.041.667.

e. Biayakonsumsi

Karyawan yang bekerja di Batik Celaket mendapat konsumsi berupa makan siang. Untuk konsumsi yang didapat Rp 10.000. Dengan jumlah karyawan yang 7 orang dan 12 hari kerja maka biaya konsumsi yang dikeluarkan sebesar Rp 840.000.

f. Gajimandor

Mandor di Batik Celaket adalah pengelola yang mengawasi proses produksi sampai pengiriman produk kepada pemesan, selama ini belum ada pembagian gaji yang jelas untuk mandor dikarenakan yang menjadi mandor adalah keluarga dari pemilik Batik Celaket, berdasarkan wawancara dengan pimpinan gaji untuk mandor adalah sebesar Rp 500.000 per bulan.

g. Biaya air

Untuk air tiap bulannya Batik Celaket habis Rp 500.000. sedangkan pengerjaan pesanan yang dilakukan di unit usaha selama 2 minggu, makabiaya air yang digunakanRp 250.000 .

Untuk perhitungan biaya overhead pabrik berdasarkan metode job order costing dapat dilihat pada tabel berikut: 
Biaya Overhead Pabrik

Pesanan Kemeja Batik

Bulan Juni 2017

\begin{tabular}{|c|l|lr|}
\hline No. & Keterangan & Total \\
\hline 1 & Lilin & $\mathrm{Rp}$ & 400.000 \\
\hline 2 & Warna & $\mathrm{Rp}$ & 100.000 \\
\hline 3 & Bahan Bakar & $\mathrm{Rp}$ & 170.000 \\
\hline 4 & Bahan Kimia & $\mathrm{Rp}$ & 7.000 \\
\hline 5 & Biaya Penyusutan Peralatan & $\mathrm{Rp}$ & 31.567 \\
\hline 6 & Biaya Sewa & $\mathrm{Rp}$ & 1.041 .667 \\
\hline 7 & Biaya Konsumsi & $\mathrm{Rp}$ & 840.000 \\
\hline 8 & Biaya Gaji Mandor & $\mathrm{Rp}$ & 500.000 \\
\hline 9 & Biaya Air & $\mathrm{Rp}$ & 250.000 \\
\hline Total Biaya Overhead & $\mathrm{Rp} 3.340 .234$ \\
\hline \multicolumn{2}{|l}{ Total Biaya Overhead per Unit } & $\mathrm{Rp}$ & 33.402 \\
\hline
\end{tabular}

Sumber: Data diolah, 2017

Dari uraian sebelumnya dapat kita tentukan harga pokok produksi yang ditetapkan menggunakan metode job order costing pada Batik Celaket. Penghitungan harga pokok produksi tersebut dihitung dengan menjumlahkan biaya bahan baku, biaya tenaga kerja dengan biaya overhead pabrik yang dianggap bersangkutan dengan proses produksinya. Berikut merupakan perhitungan harga pokok produksi menggunakan metode job order costing untuk pesanan pada bulan Juni tahun 2017:

Biayabahanbaku : Rp 2.875.000

Biayatenagakerja $\quad: \operatorname{Rp} 2.880 .000$

Biayaoverhead $\quad: \underline{\operatorname{Rp} 3.340 .234}$

Total $\quad: \operatorname{Rp} 9.095 .234$

HPP per Unit $\quad:$ Rp 90.952

Kartu harga pokok produksi pesanan merupakan catatan yang penting dalam metode harga pokok pesanan. Kartu harga pokok ini berfungsi sebagai rekening pembantu, yang digunakan untuk mengumpulkan biaya produksi tiap pesanan produk. Biaya produksi untuk mengerjakan pesanan tertentu dicatat secara rinci di dalam kartu harga pokok pesanan yang bersangkutan. (Mulyadi, 2010:44)

Setelah pembiayaan direkap berdasarkan pengelompokannya, baru di masukkan ke kartu harga pokok. Penetapan harga jual merupakan keputusan penting yang harus dilakukan oleh unit usaha. Karena keputusan ini berkenaan langsung ke konsumen yang akan 
menentukan membeli produk atau tidak. Apabila harga jual yang ditentukan unit usaha terlalu tinggi maka akan menyebabkan daya saing di pasarnya dan salah satu dapaknya pelanggan enggan membeli. Namun apabila harga terlalu rendah maka akan berdampak pada kelangsungn usaha yaitu penerimaan laba yang tidak sesuai target dan dampak berkepanjangan yang akan membuat unit usaha mengalami kerugian.

Dalam menentukan harga jualnya, Batik Celaket mengambil keuntungan 12\% dari harga pokok produksinya. Menurut Garisson (2006:531) pendekatan yang umum dalam penentuan harga adalah mark-up biaya. Mark-up produk adalah perbedaan antara harga jual dengan biayanya yang biasa dinyatakan sebagai persentase dari biaya. Rumus yang digunakan untuk menghitung harga jual pada metode ini adalah :

Harga Jual $=$ Biaya $+($ persentase mark- $u p$ x biaya $)$

Persentase mark-up yang digunakan oleh Batik Celaket adalah 12\%. Berikut merupakan perhitungan harga jual berdasarkan perhitungan harga pokok produksi metode Job order costing :

$$
\begin{aligned}
& =\mathrm{HPP}+(12 \% \times \mathrm{HPP}) \\
& =\operatorname{Rp} 90.952+(12 \% \times \operatorname{Rp} 97.088) \\
& =\operatorname{Rp} 90.952+\operatorname{Rp} .10 .914 \\
& =\operatorname{Rp} 101.866
\end{aligned}
$$

Menurut perhitungan harga jual dengan metode mark-up berdasarkan harga pokok produksi metode job order costing diperoleh harga per unit kemeja batik cap sebesar Rp 101.866 yang kemudian dibulatkan menjadi Rp 102.000.

Perhitungan Harga pokok produksi menyebabkan perusahaan dapat menghitung sesuai takaran yang benar yang berakibat pada pendapatan yang diterima bisa dicapai diatas pengeluaran biaya produksi. Sesuai makna dari surat Al-Isra' ayat 35, hal itulah yang paling utama dan benar akibatnya. Dengan menghitung secara benar biaya produksi yang dikeluarkan, maka perusahaan diharapkan bisa mendapat laba sesuai yang diharapkan.

Hal tersebut juga tidak boleh terlepas dari akad antara kedua belah pihak. Sesuai dari hadis riwayat Ahmad Nabi Shalallahu 'Alaihi wa Sallam bersabda:

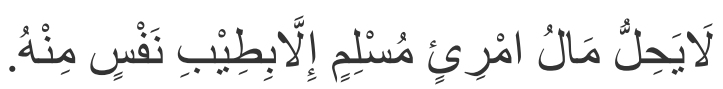

“Tidaklah halal harta seorang muslim kecuali dengan dasar kerelaan jiwanya”. (HR. Ahmad, dan dishahihkan oleh al-Albani dalam Shahih at-Targhib wat Tarhib no. 839) Dengan langah-langkah dari implementasi metode job order costing yang sudah dijabarkan. Maka perusahaan bisa memperkirakan berapa pengeluaran selama produksi dan 
dapat menentukan harga jual dengan tepat, sehingga terjadi saling rela diantara kedua belah dan khususnya bagi perusahaan agar bisa mendapatkan laba sesuai yang diharapkan.

\section{SIMPULAN}

Berdasarkan analisis dan pengamatan di lapangan mengenai harga pokok produksi pada Batik Celaket Malang, maka dapat ditarik kesimpulan bahwa unit usaha Batik Celaket Malang belum menghitung harga pokok produksi dengan tepat dalam penentuan harga jual, dikarenakan Batik Celaket tidak membuat laporan keuangan.Berdasarkan analisis terhadap perhitungan biaya produksi dengan metode job order costing, peneliti mendapatkan hasil perhitungan harga pokok produksi (seperti yang telah dijelaskan di halaman 77) total $\mathrm{Rp}$ 9.095.234 dengan biaya produksi per unit Rp 90.952. Harga berdasarkan kebijakan dengan margin $12 \%$ adalah $12 \%$ x $\mathrm{Rp} 90.925=\mathrm{Rp} 101.866$ dibulatkan menjadi $\mathrm{Rp}$ 102.000.Penggunaan metode job order costing sebaiknya dilakukan dalam perhitungan harga pokok produksi pada pesanan karena dapat memberikan informasi biaya pokok produksi yang lebih jelas dan lengkap sehingga memberikan informasi yang lebih akurat dalam penentuan harga jual yang kemudian diharapkan dapat mendapat laba sesuai yang diinginkan. 


\section{DAFTAR PUSTAKA}

Al Qur'an al-Karim danterjemahan.

AchmadSyaiful. 2013. Kota Malang akanMiliki Sentra Batik, (Online), diakses 29 Agustus 2017.(http://mediacenter.malangkota.go.id/2013/11/kota-malang-akan-miliki-sentrabatik)

Ara. 2017. Pengusaha Kecil Dorong Pertumbuhan Ekonomi Malang, (Online), diakses 16 November 2017. (http://www.aremamedia.com/pengusaha-kecil-dorongpertumbuhan-ekonomi-malang/)

Bank Indonesia. 2017. Undang-UndangRepublik Indonesia Nomor 20 Tahun 2008 Tentang Usaha Mikro, Kecil, Dan Menengah, (Online), diakses 29 Agustus 2017. (http://www.bi.go.id/id/tentang-bi/uu-bi/Documents/UU20Tahun2008UMKM.pdf)

BidangInformasiPublik, 2016, Kota Malang RaihPenghargaanNatamuktiPranata, (Online), diakses 29 Agustus 2017. (http://malangkota.go.id/2016/11/30/kota-malang-raihpenghargaan-natamukti-pranata/)

Blocher, Edward J, Stout, David E ,dan Gary Cokins. 2011.Cost Management: AStrategoc Emphasis (ManajemenBiaya: PenekananStrategis). Jakarta: SalembaEmpat

Garrison, Ray H., Norren, Eric W., dan Peter C. Brewer. 2006. ManagerialAccounting (AkuntansiManajemen)Edisi 11, Buku 1. Jakarta: SalembaEmpat

Hansen, Don R. And Mowen, Maryanne M. 2000. Manajemen Biaya: Akuntansi dan PengendalianEdisi 1, Jilid 1. Jakarta: Salemba Empat

Mulyadi. 2015. Akuntansi Biaya. Yogyakarta: UPP STIM YKPN 